\title{
フェロモンコミュニケーションを利用した 自律移動型センサ群による監視の高信頼度化
}

\author{
石垣陽*田中健次*. 伊藤 誠**
}

Autonomous Mobile Sensors System Communicating by Pheromone for Reliable Monitoring ${ }^{\dagger}$

Yo ISHIGAKI* Kenji TANAKA* and Makoto ITOH**

\begin{abstract}
This paper proposes a safety monitoring system by small number of autonomous sensors. High-reliable safety monitoring system is vital to operate large-scale systems, such as nuclear power plants. Monitoring by multiple and fixed sensors is effective, but it requires large cost. Also, in nuclear systems, there are difficult places to fix sensors for long time since a sensor has weakness for radiation near a nuclear reactor. Thus, this paper proposes a reliable autonomous and distributed monitoring system by small number of sensors.

There are three requirements for the autonomous monitoring system from aspect of reliability. The first one is that several sensors should aggregate to prevent false alarms when a sensor detects abnormal situation, and that then they should diffuse efficiently all over the objected area to prevent lack of alarms. The second is that a frequency of sensors' visit should be constant for every point in area when the monitored area is homogeneous. The last is that the frequency should be controllable depending on the priorities when the monitored area is heterogeneous. The monitoring system that this paper proposes is an Ant-like Sensor System (ASS) that consists of autonomous sensors communicating by pheromone. In ASS, each sensor agent moves around leaving the markings of repulsive pheromone that means that some sensor has visited the surveillance point. Such pheromone communication makes sensors system satisfy the above three requirements.

Two experiments are conducted to clarify the condition to assign optimal parameters for ASS, such as quantity of sprayed pheromone and evaporation speed of pheromone. The optimal parameters are determined dependent on the number of sensors and the characteristics for monitored area.
\end{abstract}

Key Words: safety monitoring system, swarm intelligence, false alarm and lack of alarm, reliability, real-time search

\section{1.はじめに}

原子力発電所, 大規模化学プラント, 超高層ビルなどの施 設においては，誤報・欠報といったセンサの誤動作を防ぎ， 高信頼度に異常を発見するための安全監視システムが不可欠 である. 誤動作を防ぐためには， $N$ 個の同質センサであれ ば, $k$-out-of- $n$ 型の論理構成が有効である ${ }^{1)}$. しかし複数の センサを多数の監視地点に固定することは経済的に難しい2) (Fig.1(a)). そこで，この問題を解決するため, 本研究で は，少数センサ群による自律移動型の監視システムに注目す

†第 14 回自律分散システム・シンポジウムで発表 $(2002 \cdot 1)$

* 電気通信大学大学院情報システム学研究科 調布市調布々丘 $1-5-1$

** 筑波大学電子・情報工学系 つくば市天王台 1-1-1

* Graduate School of Information Systems, University of Electro-Communications, Chofu, Tokyo

** Institute of Information Sciences and Electronics, University of Tsukuba, Tsukuba (Received April 24, 2003) (Revised September 17, 2003)
る(Fig. 1(b)).

本稿ではまず，監視の信頼性の観点から，自律移動型セン サ群に求められる要求を考える。つぎに, フェロモンコミュ ニケーションを利用したセンサ群の自律分散的な制御方式を, アリ型センサシステム（ASS: Ant-like Sensor System）と して提案する。フェロモンコミュニケーションは昆虫群の協 調行動をヒントにしたモデルであり，すでにマルチエージェ ントの適応的通信手段として研究されている ${ }^{3) \sim 5)}$. 本研究 では, センサが監視したことを意味する情報を忌避フェロモ ン（repulsive pheromone）として場に埋め込むことで，セ ンサ間のフェロモンコミュニケーションを実現する。

障害物を回避するためにポテンシャル場の情報を利用した 研究もある ${ }^{6)}$ が, そ扎は静的な場の利用であり, フェロモン コミユニケーションでは, 場の情報を変化させることで動的 にコミュニケーションを進めることができる.

ASS を設計する際には, 監視対象の特性に応じて, 個々の センサエージェントが散布するフェロモンの量 (高さ・半径) やフェロモン場の特性（蒸発速度）などのパラメータをいか 


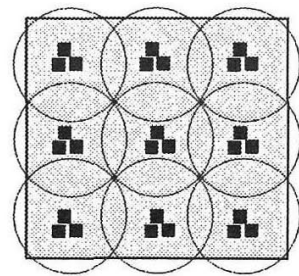

(a) Fixed sensors

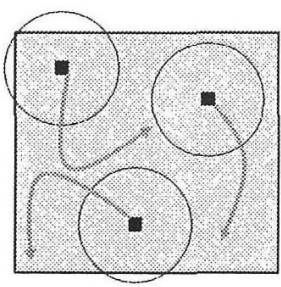

(b) Autonomous sensors
Fig. 1 Safety monitoring by autonomous sensors

にバランスよく決定すればよいかが問題となる，本研究では， センサ数や監視対象の面積・特性に応じた, 望ましいフェロ モンの散布・蒸発パラメータを明らかにする。

ASS の行動制御方式は, 実時間探索の一種である7),8). Koenig $ら^{8)}$ は, LRTA* ${ }^{*}$ Node Counting どの実時間探 索方式において，エージェントに予期せ姼動や故障などが 起きても，ロバストに空間全体を均一に探索し続けることを 示した。しかし，実時間探索を安全監視に応用することを考 えた場合，ある場所がどれだけの時間監視されないかを考虑 したり，あるいは監視対象の特性に応じて，特定の領域を重 点的に探索させる必要がある.

\section{2. 自律移動型センサシステム}

自律移動型センサシステムが，誤報・火報を防ざっっ，少 数のセンサで高信頼度な監視を行なうためには，(a) 異常を 検出した際は複数セン少が 1 箇所に集まることで誤報を防ぎ, (b) 平常時はセンサが空間内を動き回ることで欠報を防ぐ必 要がある。

(a)の動作後, センサ群は再び空間全体に効率よく拡散す ることが要求される．これを要求(1)とする。ここで効率のよ い拡散とは, 一度あるセンサによって監視された場所が, 再 度他のセンサによって監視さ扎ることなく, 空間全体にセン サ群が広がることをいう。

また (b) では, 異常の検出に遅れが生じないことが要求さ れる. Fig. 2 に, 異常を検出するための特徵量の時間的变 化を示す．異常を検出するための特徴量が，センサによって 検出できる值になったときから，事故に至るまでの時刻を critical time と呼ぶ. センサが集合し判定を下すまでの時間 や，警報を発してから対象箇所を修理するまでの時間を $\Delta$

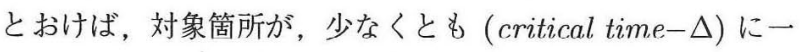
度の割合でセンサによって監視されれれば，事故を未然に防ぐ ことができると考えられる。監視対象が均質である場合, 領 域内のどの場所でも, センサが監視に訪狄る時間間隔（以下, 到着間隔と呼ぶ）がほぼ一定である（以下，空間的な分散が 少ないという)ことが要求される。これを, 要求(2)とする.

さらに, 実際の監視対象では, 場所によって critical time が異なる。したがって, critical timeに応じた到着間隔を設 定できることが要求される。これを，要求(とする。

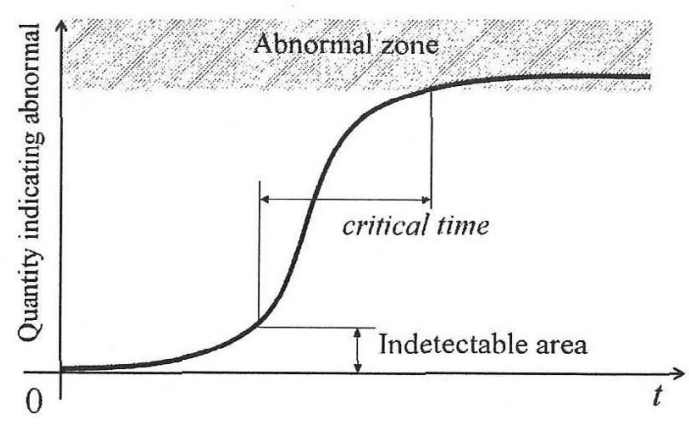

Fig. 2 Critical time and quantity indicating abnormal

\section{3. アリ型センサシステム}

\section{1 モデル}

$N$ 個のセンサエージェント（以下単にセンサという）は， 監視対象平面 $S$ 上を常に動き回る. 各センサが監視できる 範囲は, センサの位置 $(x, y)$ から, 有効監視半径 $u$ 以内の 場所とする。

フェロモンを蓄積するフェロモン場を $P(x, y)$ で表わす. 個々のセンサは $1[$ step $]$ 動くごとに, 円錐状のフェロモンを 散布する。このとき散布するフェロモンの高さを $h$, 半径を $w$ とする.フェロモン量は 1 ステップにdだけ減少するもの とし、こ札なェロモンの蒸発と呼ぶ.ただし, フェロモン が 1 つの場所に蓄積される量には最大值があるものとする. Fig. 3 は, 直進しているセンサにより各ステップで散布され たフェロモンが, 蒸発して減少しているようすの, ある瞬間 の状態を表わしたものである.

最初の時刻において, フェロモンが存在しない状態を, 初 期状態と呼ぶ.これに対して, 初期状態から時刻が十分に経 過し, フェロモン場全体に存在するフェロモンの総量が安定 している状態を，定常状態と呼ぶ。

Fig. 4 に示すとおり, センサは今いる場所でのフェロモン量 $P(C)$ と, 半径 $u$ の距離にある, 前後左右の場所でのフェロ モン量 $P(N), P(E), P(W)$ および $P(S)$ のみを知ることが できる.このとき $\min \{P(N), P(E), P(W), P(S)\}<P(C)$ であれば，つぎの時刻では $P$ が最小值をとる点に向かって移 動する（ただし，最小值をとる点が複数ある場合には，その なかから移動先をランダムに選択する)。さもなければ, 現 在の方向を維持する.

以上の規則によって，ASSでは，センサをよりフェロモン 量の少ない方へ移動させることで, 忌避フェロモンに基づい たフェロモンコミュニケーションを実現できると考えられる。

\section{2 期待される特性}

初めに要求(1)について考える. 初期状態において, 狭い範 囲にセンサが集まっていると, センサ群は, 互いの出すフェ ロモンを検出し合い, 互いの距離が大きくなる方向に向かっ て動き出すことが予想できる，さらに，初期状態ではフェロ モンが全くないので, センサ群は, 対象空間全体を少なくと も 1 回，〈まなく監視する特性があると考えられる。センサ 


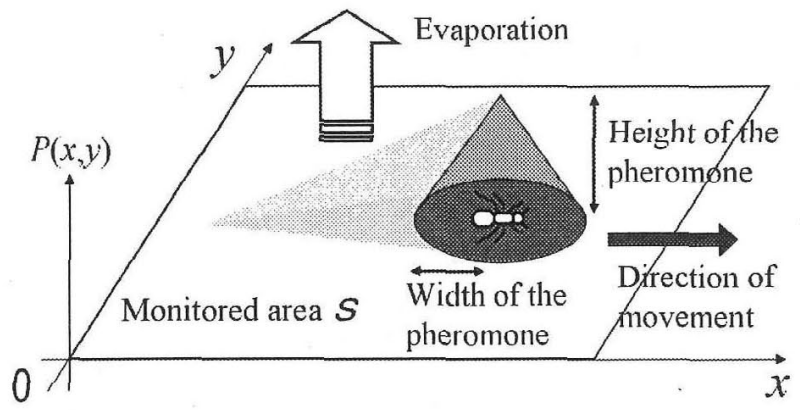

Fig. 3 Ant-like sensor secreting pheromone

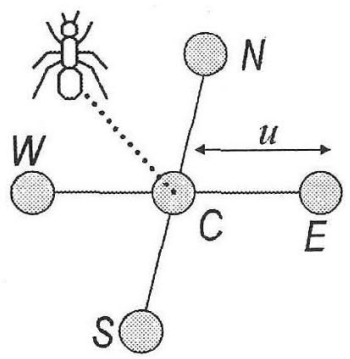

Fig. 4 Sight of sensor agents

が集合している状態から効率よく拡散し，いずれは対象空間 全体をくまなく監視する特性を，拡散監視特性と呼ぶ。ASS が要求(1)を満たすためには，この特性を発現する必要がある.

つぎに要求(2)について考える。最近センサが通った場所は, それ以前にセンサが通った場所に比べ，フェロモンがより多 く残るため, 再びすぐには監視されにくい.しかし一定の時 間が経つとフェロモンが蒸発し，再び監視される。対象空間 内にセンサが均一に分布している場合，どの場所においても， センサの到着間隔がほほ一定になると考えられる。これを， 均一監視特性と呼ぶ. ASSが要求(2)を满たすためには，この 特性を発現する必要がある。

最後に要求(3)について考える. 監視対象空間内で, 領域に よってフェロモン点発速度に差異をつけると, 蒝発の速い領 域では忌避フェロモンが早く無くなり，七ンサの到着間隔が 短くなることが予想される。特定の領域での到着間隔を制御 することができる特性を, 重点監視特性と呼ぶ. ASSが要求 (3)を满たすためには，この特性を発現する必要がある。

\section{3 評価尺度}

ASS が要求(1)(2)(3)を満たす程度を評価するために，初期被 覆洔間 (first cover time: FCT) と最大到着間隔 (maximum turn-around time: MTT) の, 2 つの評価尺度を定義する.

FCT は, 拡散監視特性がどれだけ有効に発現し, 要求(1) を满たしているかを評価する尺度である．FCT $(p)$ は監視対 象空間の面積 $S$ の $p \%$ を被覆（監視）するまでの最小時間で あり，以下の単位被覆関数 $\omega(x, y, t)$ を用いて定義する。

$$
\begin{array}{ll}
\omega(x, y ; t)=1: & \text { 時刻 } t \text { において, } 1 \text { つ以上のセンサが, } \\
& \text { 有效監視半径 } u \text { 以内に点 }(x, y) \text { を含む. } \\
\omega(x, y ; t)=0: & \text { 時刻 } t \text { において, どのセンサも, 有効監 } \\
& \text { 視半径 } u \text { 以内に点 }(x, y) \text { を含まない. }
\end{array}
$$

時刻 0 から $T$ までにセンサ群が監視した総面積 $C(T)$ は,

$$
C(T)=\sum_{x, y} \max \{\omega(x, y ; t) \mid 0 \leq t \leq T\}
$$

と表わされ， $C(T)$ を用いて, FCT を次で定義する。

・初期被覆時間（FCT）

$$
\operatorname{FCT}(p) \stackrel{\text { def }}{=} \min \left\{t \mid C(t) \geq S \frac{p}{100}\right\}
$$

FCTが小さいほど，センサ群が監視対象空間に効率よく 拡散したことを意味する。

一方の MTTは, 要求(2)と要求(3)をどれだけ満たしている かをみる尺度であり，次で定義する。

・最大到着間隔（MTT）

$\operatorname{MTT}(x, y ; T)$ : 定常状態において, 区間 $[0, T]$ で, 連続 して $\omega(x, y, t)=0$ となる時間幅のなか で最大の值。

MTTの, 監視対象内での空間的な標準偏差 $\sigma(\mathrm{MTT})$ を みることによって, 要求(2)を満たす程度を評価することがで きる。 $\sigma(\mathrm{MTT})$ が小さいほど，対象空間を均一に監視したこ とを意味する。

さらに, 蒸発速度と MTT の空間平均 $\overline{\mathrm{MTT}}$ との関係を 知ることで，要求(3)を满たす程度を評価することができる。 $\overline{\mathrm{MTT}}$ が相対的に小さい領域では, 重点的に監視が行なわれ たことになる。

\section{4. 実 験 I}

実験 I では，個々のセンサエージェントの散布するフェロ モンの高さ $h$ と半径 $w$ がどのような值の組みをとるとき, アリ型センサシステムが自律移動型センサシステムへの要求 (1)(2)を满たすことができるかについて考える.

\section{1 仮説}

センサ数を $N$, 監視対象空間の面積を $S$, 定常状態におい て1つのセンサから散布されたフェロモンの底面積を $S_{1}$ と する， $S_{1}$ は，Fig. 3で散布さ机ているフェロモンを，上から みたときの面積に等しい。 以下で, 散布されるフェロモンの 総面積 $N \times S_{1}\left(N S_{1}\right.$ と記す）と $S$ との比較を考える.

$N S_{1}<S$ のとき, フェロモンの蒸発速度が早いために, フェロモンの勾配情報が失われる範囲が多くなり, フェロモ ンによる情報を有効に利用できない（Fig.5(a)）。こうした 現象を散漫と呼ぶ.

逆に $N S_{1}>S$ の場合は, フェロモンが過剩に散布される ため, センサ近傍でフェロモンが最大值に達し, 勾配情報が 失われる可能性が高い (Fig. 5(c))。こうした現象を輻輳と 呼今゙.

散漫・輻輳のどちらも，フェロモンの情報を有効に利用でき ない状況であり，避けることが望ましい。そして，NS $=S$ のとき, 輻輳・散漫のどちらの状態にも陥ることなく, 拡散 監視特性と均一監視特性が最も有効に発現すると予想される (Fig. 5(b)). 以上の考察から，以下の仮説をたてる. (仮説) $N S_{1}=S$ のとき, FCT と $\sigma(\mathrm{MTT})$ が最小となる， 


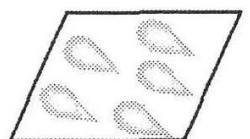

(a) $N S 1<S$

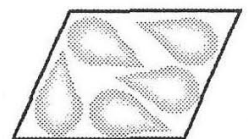

(b) $N S_{1}=S$

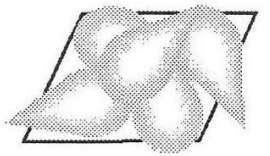

(c) $N S \mathrm{I}>S$
Fig. 5 The balance between $N S_{1}$ and $S$

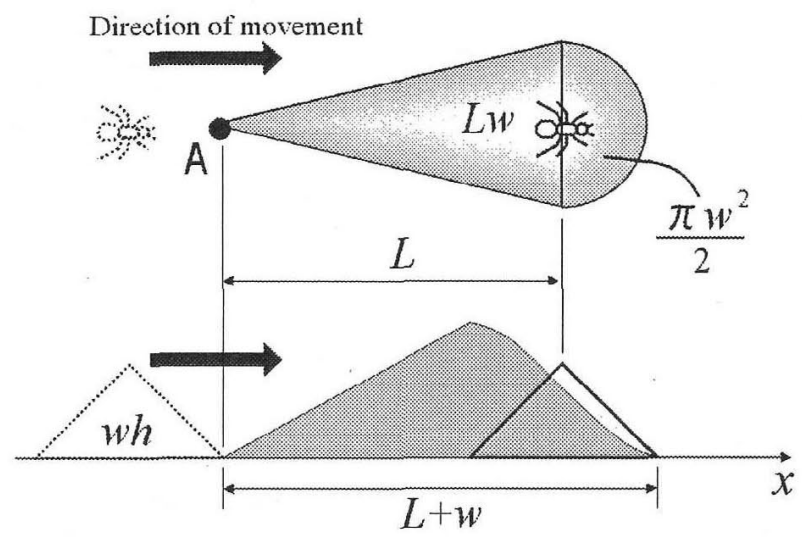

Fig. 6 Approximation of pheromone-covered area

これを $N S_{1}=S$ の仮説と呼ぶ. ここで, $N S_{1}=S$ の仮説 が成り立つとき, フェロモン散布の高さ $h$ と半径 $w$ がどの ような関係になるかを考える。セン州が直進している場合, $S_{1}$ は, 三角形と半円の面積で近似すると, Fig. 6 より,

$$
S_{1}=L w+\pi w^{2} / 2
$$

と表わすことができる。ここで $L$ は, 散布されたフェロモン の尾の長さである. 散布された総フェロモンの断面は, 厳密 にはFig. 6 に示す通り, その頂点がセンサの位置よりも後方 となる。

点 $\mathrm{A}$ に初めてフェロモンが散布されてから, 蒝発によっ てフェロモンが無くなるまでの時間は, センサの移動速度が $1[\mathrm{grid} / \mathrm{step}]$ であることから,$L+w$ で表わすことができる. したがって, Aにおいて蒸発するフェロモンの総量は, 点発 速度 $d$ と移動時間 $L+w$ の積で求められる. 一方, $\mathrm{A}$ に散 布されるフェロモンの総量は $w h$ であり, 蒸発と散布のフェ ロモン量は等しいので，次式が成立する.

$$
d(L+w)=w h
$$

(3) と (4) から $L$ を消去する.

$$
\begin{aligned}
S_{1}= & (\pi / 2+h / d-1) w^{2} \\
& \text { ただし }, h, w, d>0
\end{aligned}
$$

$N S_{1}=S$ が成立するとき, $h$ と $w$ は次式を满たす.

$$
N(\pi / 2+h / d-1) w^{2}=S
$$

\section{2 実験の目的と方法}

実験 I の目的は, $N S_{1}=S$ の仮説が成り立つか否かを確 かめることである. 実験は, 計算機シミュレーションによっ て行なう。監視対象空間は, $50 \times 50$ のグリッド $(S=2500)$ で構成し, センサ数 $N=5$, センサの有効監視半径 $u=5$
および蒸発速度 $d=1$ にそ机ぞれ固定し，センサの移動量は 1 [step $]$ あたり 1 [ grid $]$ とする.フェロモン散布の高さ $h$ と 半径 $w$ を 1 から 30 までの整数值で変化させ, 900 の $h$ と $w$ の組み（以下, パラメータセットと呼ぶ）における初期被 覆時間 FCT および, 最大到着間隔の標準偏差 $\sigma(\mathrm{MTT})$ の值 を測定する。フェロモン場に存在するフェロモン量は整数值 で表わし, 最大值は 255 , 最小值は 0 とする. センサの初期 配置はランダムに決めた。

以下で, FCT と $\sigma(\mathrm{MTT})$ それぞれの測定方法を示す.な お，(1)と (2) は別々に実験を行なった.

(1) FCTについて

最大 $T=200[$ step $]$ まで, FCT の測定を行ない, これを 1 trial とする. 各パラメータセットごとに, 100trial の実験 を行ない, それらの平均值を, そのパラメータセットでの評 価值とする。

(2) $\sigma(\mathrm{MTT})$ について

測定は, 初期状態から十分に時間が経過し, 定常状態となっ た時刻から行なう。 $T=400[s t e p]$ までの, $\operatorname{MTT}(x, y ; T)$ の 空間的な標準偏差 $\sigma(\mathrm{MTT})$ を測定し, これを 1 trial とする. 各パラメータセットごとに, 100trial の実験を行ない, それ らの平均值を，そのパラメータセットでの評価值とする。な お，期間 $T[s t e p]$ の間に，ある領域に一度もセンサが存在し なかった場合は, その領域の $\overline{\mathrm{MTT}}$ を $T$ とする.

\section{3 実験結果と考察}

4.3.1 FCT とパラメータ $h, w$

実験 I におけるFCT(90\%)の図（Fig。7）から,つぎの結 果が得られる。

(a) $\mathrm{FCT} の$ 值が小さい領域付近では, その值は $h$ よりも $w$ に大きく依存して変化する。

FCTの值は, $h$ が変化しても安定している.たとえば, $w=7$ のときの断面をみると, $h>8$ であれば FCT が小さ い值で安定している.これに対し $h$ が一定のとき， $w$ の変 化に刘して，FCTは人きく増加する．たとえば $h=15$ のと き, $w$ が 6 から 11 の間あたりで FCTが小さい值をとり, $w$ の值がこの範囲から外机ると大きく増加する.

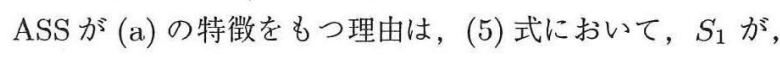
$h$ に関しては 1 次式だが, $w$ に対しては 2 乗に比例している ことから説明できる。

Fig. 8 に $h=15$ に固定し, $p$ を变化させたときの FCT $(p)$ を示す. Fig. 8からつぎのことが得られた。

(b) $p$ を大きくするほど, FCTを小さい值に保つために許容 できるパラメータ $w$ の範囲は, 輻輳側（ $w$ の值が大きい側） から狭まる。

ASSが (b) の特徵をもつ理由は，つぎで説明される. Fig. 9 に示す通り, $w$ が大きい值では, 1 つのセンサから忌避フェ ロモンが広範囲に散布される。そのため, センサが通った領 域付近では，まだ一度も監視されていない場所であっても， 十分な時間が経過してフェロモンが蒸発するまでは, センサ による監視が行なわれない場合がある。こうした場所は， $w$ 


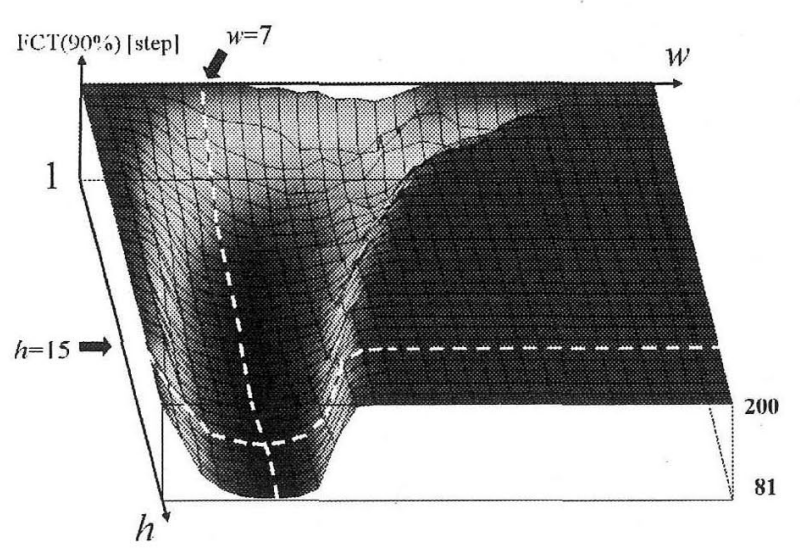

Fig. 7 FCT(90\%)

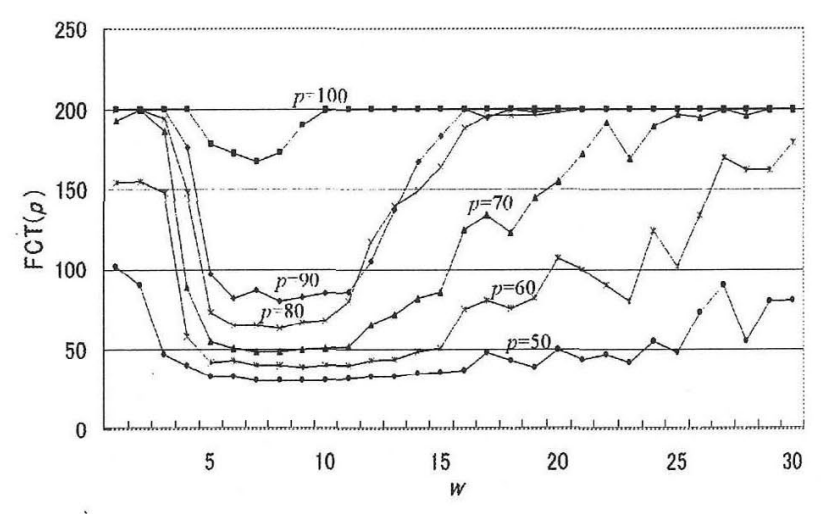

Fig. $8 \mathrm{FCT}(p)$ for $h=15$

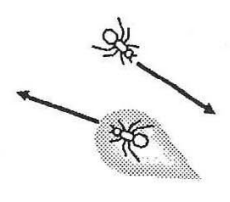

(a) $w$ is the optimal value

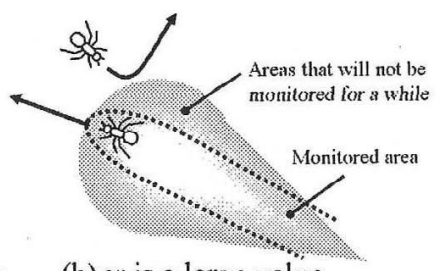

(b) $w$ is a large value
Fig. 9 Pheromon-covered area and motion of sensors

が大きくなるほど多くなる。したがって,$p$ が大きくなれば, それに伴って許容できる $w$ の範囲が輻輳側から狭くなると 考えら狄る。

$4.3 .2 \sigma(\mathrm{MTT})$ とパラメータ $h, w$

Fig. 10 は, 対象空間内における最大到着間隔の標準偏差 $\sigma(\mathrm{MTT})$ と, 高さ $h$ 抢よび半径 $w$ との関係を示している. これより，つぎの結果が得られる.

(c) $\sigma(\mathrm{MTT})$ の值が小さい領域付近では, $\sigma(\mathrm{MTT})$ の值は, $h$ よりも $w$ の変化によって大きく変わる.

これは, $\sigma(\mathrm{MTT})$ が小さい領域付近に注目すると, $h$ が変 化しても $\sigma(\mathrm{MTT})$ の変化が小さいことを意味する. たとえ ば $w=6$ のときの断面をみると， $h>9$ であれば $\sigma(\mathrm{MTT})$ は低い值で安定する，こ扎に対し， $h$ を一定として， $w$ が $\sigma(\mathrm{MTT})$ を小さな值に保つ範囲から冕脱すると, $\sigma(\mathrm{MTT})$ は大きく増加する。たとえば $h=15$ のとき, $\sigma(\mathrm{MTT})$ が低 い值で安定するのは $w$ が 5 から 8 までの間であり,これを

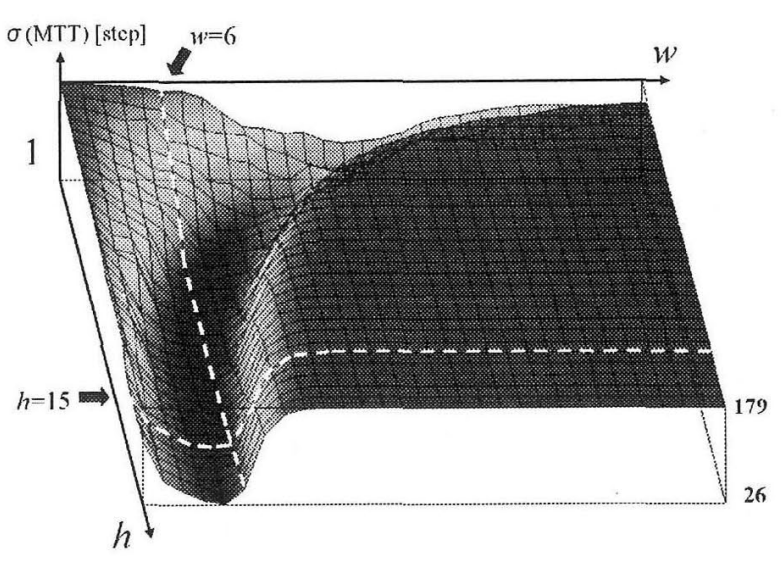

Fig. $10 \sigma(\mathrm{MTT})$

外れると大きく増加する．これらの特徵をもつ理由は，(a) の場合と同様に説明できる。

\section{3 .3 仮説の妥当性}

Fig. 11(a)(b) は，Fig. 7 およびFig.10を，それぞれ上か らみた等高線図である. 図中の 2 次曲線は, $N S_{1}=S((6)$ 式参照）を満たす高さ $h$ と半径 $w$ のパラメータセットを表 わしている. FCT および $\sigma(\mathrm{MTT})$ が最小となる領域がこの 2 次曲線と一致するならば，その領域において $N S_{1}=S$ の 仮説は妥当であるということができる.

Fig. 11(b) より， $\sigma(\mathrm{MTT})$ が小さい值で安定している領域 は，ほほ 2 次曲線に当てはまることがわかる。したがって $\sigma(\mathrm{MTT})$ については，ほほ仮説が成り立つとみてよい。

しかし Fig. 11(a)では, 放物線よりも右下（輻輳）寄りの 領域に, FCT の值が小さい部分が集中している。こ机はつ ぎで説明できるＦCTの実験は，フェロモン場にフェロモ ンが全く存在しない状態から行なわ机るため, 初期状態から $L+w[s t e p]$ が経過して初めて, Fig. 6 に示す分布状態とな る.したがってそれ以前では, 1 つのセンサが出すフェロモ ンの面積は $S_{1}$ よりも小艺い.この面積の不足を埋めなくて はならないため, 若干輻輳寄りの領域 $\left(N S_{1}>S\right)$ に, FCT の值の小さい部分が偏在したものと考えられる.

以上の考察から, 仮説の妥当性についてつぎの 2 つがいえ る.

(d) FCTが小さい值で安定するパラメータセットは, 若干輻 輳寄りではあるものの，ほほ仮説の (6) 式に当てはまる.

(e) $\sigma(\mathrm{MTT})$ が小さい值で安定するパラメータセットは，ほ ほ仮説の (6) 式に当てはまる.

なお，センサの移動方向をランダムに設定し同条件での 実験を行なったところ, FCT $(90 \%)$ は 200[step] では達せ ず, $\sigma(\mathrm{MTT})$ は $112[$ step] であった. ASS の示す最小值は, $\operatorname{FCT}(90 \%)$ が 81[step], $\sigma(\mathrm{MTT})$ が 26[step] であり（Fig. 7, 10),いず扎 ASSのほうが望ましい.

\section{4 まとめ}

考察 (d)より, ASS が均一監視特性を有効に発現し, 要求 (2)を満たすためには，仮説の (6) 式に当てはまるパラメータ セットよりも, 若干輻輳寄りに設定すればよいことがわかっ 


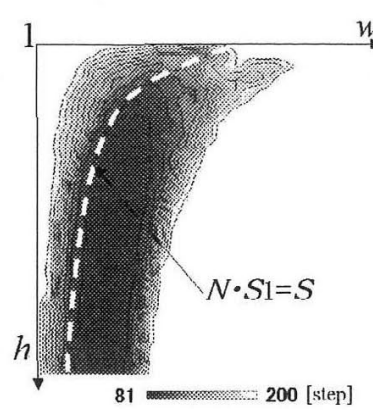

(a) $\mathrm{FCT}(90 \%)$

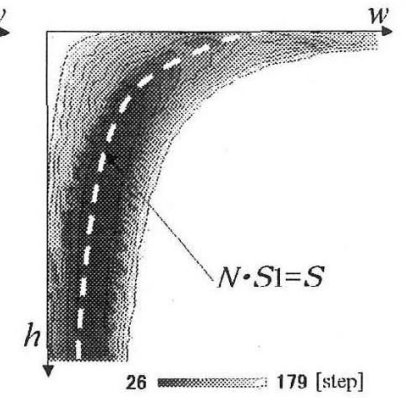

(b) $\sigma(\mathrm{MTT})$
Fig. 11 Topographic plots of $\mathrm{FCT}(90 \%)$ and $\sigma(\mathrm{MTT})$

た。また考察 $(\mathrm{e})$ より，搪散監視特性を有効に発現し，要求 (1)を満たすためには， $h$ と $w$ を仮説の (6) 式に当てはまる 值に設定すればよいことがわかった。

ASS では, 要求(1)と(2)はシステムの運用時に継ざ目無く 要求さ机るものであるため, 両方を同時に满足する必要があ る. 要求(1)と要求(2)を同時に渵たすための方策としては，つ ぎの 2 つが考えら机る。

方策 1 は, 要求(1)(2)を同時に满足する, $h$ とwの組みを 見つけることである。この方策をとる場合，考察 (a)(c)より， $h$ よりもwの值を慎重に定める必要がある. また考察 (b) か ら，何\%の面積まで効率よく拡散する必要があるか，という 運用上の制約によって，FCTを最適に保っために許容でき るパラメータ $w$ の範团が変化する，すなわち，方策 1 をと る場合， $p$ を何\%に設定するかが重要となる。

方策 2 は, 状況に応じて, センサ自身がフェロモンの散布 パラメー夕を変化させることである。たとえば初期状態では $w$ を(6)の示す值よりも輻輳寄りにし，定常状態に入ったと 判断した際は, $w$ を(6)の示す值に戻す，という制御が考兄 られる。この方策をとる場合, センサが自律的に, 初期状態 か定常状態かを判断する必要がある。

\section{5. 実 験 II}

実験 II では, ASS が要求(3)を满たすか否かを知るために, 監視対象内の領域により危険な状況が異なり, critical time が同一でない場合を想定する，蒸発速度の制御によって $\overline{\mathrm{MTT}}$ が制御可能であ机ば，ASS は要求(3)を满足することになる. そこで, 領域間における蒸発速度 $d$ に差異をつけたとき, 各 領域に拉ける最大到着間隔の平均值 $\overline{\mathrm{MTT}}$ がどのように変化 するかを調べる。

dがフェロモン場の特性を示すパラメータであるのに対し， $h$ 押よびwはセンサの特性を示すパラメータである. $h$ お よび $w$ は常に一定の值とし,$d$ に差異をつけるだけで $\overline{\mathrm{MTT}}$ を制御できれば，センサはどの領域に位置していても，常に 一定のフェロモンを散布してい扎ば良く，位置情報を知る必 要がない.

本実験では，監視対象空間を，Fig. 12 に示すとおり，左 右 $2 つ の$ 領域に分ける。簡単のため, 2 つの領域の面積は等

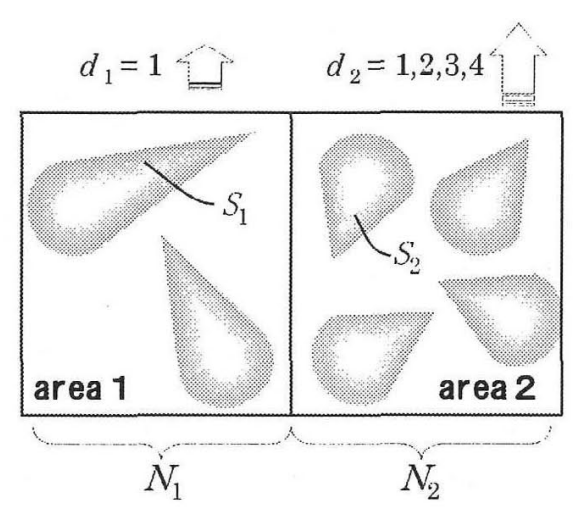

Fig. 12 Two areas with different evaporate speeds of pheromone

しいものとする。領域 $1 ， 2$ それぞれにおけるフェロモンの 蒸発速度が $d_{1}, d_{2}$ のとき, 各領域での最大到着間隔の空間 平均 $\overline{\mathrm{MTT}_{1}}, \overline{\mathrm{MTT}_{2}}$ がどのように变化するかを考える.

\section{1 蒸発速度と $\overline{\mathrm{MTT}}$}

領域 1，2において，1つのセンサによって散布されたフェ ロモンの面積をそ扎ぞ机 $S_{1}, S_{2}$ と扔く(Fig. 12). 忌避フェ ロモンの面積が大きい領域は，その面積が小さい領域に比べ, 相対的に存在するセンサの数が少なくなると考えら机る。た とえば Fig. 12 の例では，領域 2 により多くのセンサが集ま ることになる。

監視対象空間全体でのセンサ数を $N$ とし, 領域 1,2 に おいて, 平均的に存在するセン州数を $N_{1}, N_{2}$ と仮定する. 領域 1 および 2 それぞれにおいて, $N_{1} S_{1}=S / 2$ および $N_{2} S_{2}=S / 2$ の関係が成り立つとき, 実験Iから, 各領域に おける $\sigma(\mathrm{MTT})$ が最小となることが予想される.

本実験では，フェロモン散布の高さ $h$ は一定とする。半 径 $w$ は， $d_{1}$ および $d_{2}$ に対して, 適当な $N_{1}, N_{2}$ (ただし $\left.N=N_{1}+N_{2}\right)$ が存在して, $S / 2=N_{1} S_{1}=N_{2} S_{2}$ の関係 が成り立つ值に設定する。ただし $w$ はすべてのセンサに共 通の値とする。

領域 1，2 亿存在するセン州数が $N_{1}, N_{2}$ であるならば，2 つの領域の面積は等しいから $N_{1} S_{1}=N_{2} S_{2}$ となり，つぎの 関倸が成り立つ。

$$
N_{1}: N_{2}=S_{2}: S_{1}
$$

一般にセンサ数と $\overline{\mathrm{MTT}}$ は反比例の関係にあると考えられ る.この関倸が成り立つとき，(5)(7)式から，

$$
\frac{\overline{\mathrm{MTT}_{1}}}{\overline{\mathrm{MTT}_{2}}}=\frac{N_{2}}{N_{1}}=\frac{\left(\pi / 2+h / d_{2}-1\right)}{\left(\pi / 2+h / d_{1}-1\right)}
$$

となるから, 蒸発速度 $d_{1}$ および $d_{2}$ によって, 各領域に平均 的に存在するセンサ数と, 領域間の $\overline{\mathrm{MTT}}$ の比を予測できる.

\section{2 実験の目的と方法}

実験 II では，(8) 式の関係が成り立つかどうかを確かめる. 監視対象空間は実験 I と同じ $50 \times 50$ のグリッド $(S=2500)$ とし, これを領域 1 (左側半分) と領域 2 (右側半分) に分 ける. 実験 I と同様, センサ数 $N=5$, センサの有効監視半 
径 $u=5$ と.し，センサの移動量は 1 [step $]$ あたり 1 [ grid $]$ と する。

領域 1 の蒸発速度 $d_{1}$ を 1 に固定し, 領域 2 の蒸発速度 $d_{2}$ を制御変数として，1 から 5 までの整数值で変化させるとき， それぞれのパラメー夕における $N_{1}$ と $N_{2}$ および, 最大到着 間隔の空間平均 $\overline{\mathrm{MTT}_{1}}$ と $\overline{\mathrm{MTT}_{2}}$ の值を, 計算機シミュレー ションによって $T=2000[s t e p]$ まで測定し，これを 1trial とする。各パラメータごとに 100trial の実験を行ない，その 平均を評価値とする。なお，期間 $T[s t e p]$ の間に，ある領域 に一度もセンサが存在しなかった場合は，その領域の $\overline{\mathrm{MTT}}$ を Tとする

フェロモン散布の高さ $h$ は 20 に固定する.フェロモン量 は 0 から 255 までの整数值で表わす。センサの初期配置はラ ンダムに決めた。

\section{3 実験結果と考察}

$N_{1}$ と $N_{2}$ の実験值と理論値を Fig. 13 に示す. 実験值を 示すグラフのエラーバーは，全 trial における実験結果の標 準偏差を表わしている. 理論値とは，(8) と $N_{1}+N_{2}=5$ か ら計算した值である。理論值と実験值がほほ一致しているこ とから， $N_{1}$ と $N_{2}$ は (8) に示した比で，各領域に平均的に 存在していることがわかる.

つぎに, $\overline{\mathrm{MTT}_{1}}$ と $\overline{\mathrm{MTT}_{2}}$ の実験值を Fig. 14 に示す. $\overline{\mathrm{MTT}_{1}}, \overline{\mathrm{MTT}_{2}}$ の理論值は, $\overline{\mathrm{MTT}}$ がセンサ数に反比例す ることから， $d_{2}=1$ のときの実験値に，それぞれ $2.5 / N_{1}$, $2.5 / N_{2}$ (ここで， $N_{1}$ と $N_{2}$ は理論値）を乗じた值とした。 2.5 は, $d_{2}=1$ のときの, $N_{1}$ および $N_{2}$ の理論値である.

Fig. 14 から， $\overline{\mathrm{MTT}_{2}}$ の実験值は，ほぼ理論値にしたがっ ていることがわかる.しかし $d_{2} \geq 4$ では, $\overline{\mathrm{MTT}_{1}}$ の実験値 が理論值を大きく上回り，標準偏差も著しく大きくなる。こ 狄は， $d_{2} \geq 4$ では， $N_{1}$ が 1 を下回り（Fig. 13），センサが 領域 1 に全く存在しない時間帯があるためと考えられる．本 シミュレーションは，領域 1 にセンサが 1 つもない状態では， $\overline{\mathrm{MTT}_{1}}$ は最大ステップ数 $T$ の值をとる.このため $d_{2} \geq 4$ では， $\overline{\mathrm{MTT}_{1}}$ が理論値を大きく上回ったと考えられる。

\section{4 まとめ}

蒸発速度 $d$ に差異をつけることで， $\overline{\mathrm{MTT}}$ を制御できるこ とから, ASS は, 要求(3)を満足するシステムということがで きる. $\overline{\mathrm{MTT}}$ の比の值は, 領域内の平均センサ数が 1 を下回 らない限り，ほほ (8)が成り立つため，全体が同じ蒸発速度 のときの $\overline{\mathrm{MTT}}$ を基準に，適当な $d$ を領域ごとに決定する ことができるＡSSを設計する際には，領域内の平均センサ 数が 1 を下回らないよう， $d$ の值を設定する必要がある.

\section{6. おわりに}

本研究では，アリ型センサシステム（ASS）が，監視の信 頼性の観点から自律移動型センサシステムに求められる要求 (1)(2)(3)を満足するシステムとなりえることを示した。今後 は，要求(1)(2)を同時に満たすために， 4.4 節で議論した $2 つ$ の方策の具体的な実現方法について検討したい。また，実際

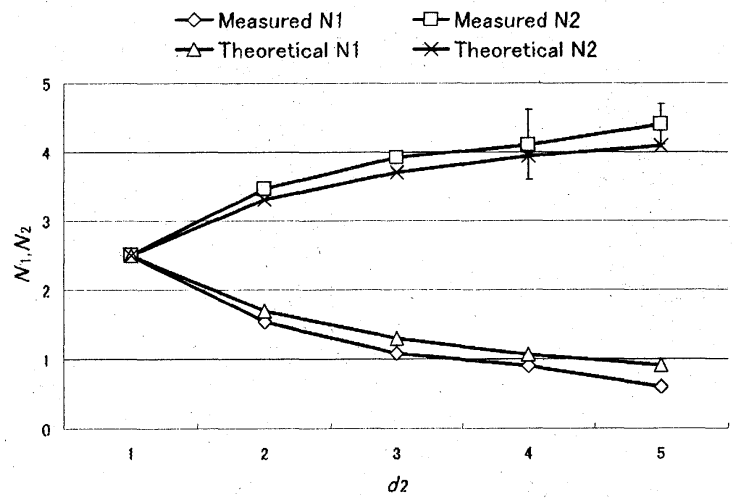

Fig. 13 The number of sensors, $N_{1}$ and $N_{2}$

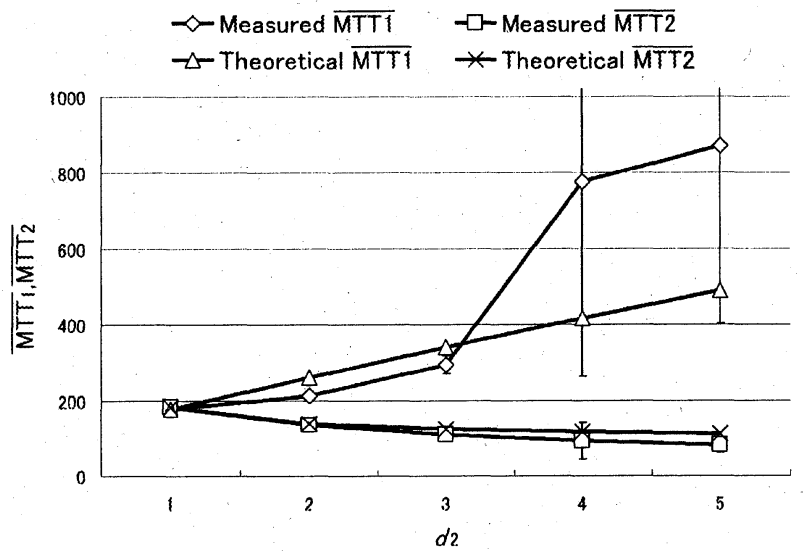

Fig. $14 \overline{\mathrm{MTT}_{1}}$ and $\overline{\mathrm{MTT}_{2}}$ versus $d_{2}$

の運用環境においては, critical-time や面積の異なる複数の 監視対象領域が混在すると考えられ，こうした場合でも，要 求(3)を満たすことのできるモデルを検討する必要がある。

ASSでは，忌避フェロモンだけを用いるのではなく，誘因 フェロモンを用いることで，異常検出時にセンサを 1 箇所に 集めることも可能と考えられる。しかし必要な数だけセンサ を集めるためには，誘因フェロモンをどのように散布したら よいかが問題となる.

また，ASSを実現する際には，フェロモン場の情報をど のような方法で蓄積し，センサ群がどのような通信手段で その情報にアクセスするかが問題となる。これについては， たとえば，知的データキャリア (Intelligent Data Carriers: IDCs $)^{9)}$ と呼ばれる，通信・情報処理機能を有する小型の装 置を用いる方法が考えられる. IDCs を監視対象領域内の各 所に設置し，これらの内部にフェロモン場の情報を分散的に 蓄積し，各センサが局所的に IDCs と通信を行なうことで, フェロモン情報の取得・更新を行なうことが可能と考えられ る.このとき，フェロモンの情報が分散しても，要求(1)(2)(3) を十分に満足するモデルを検討する必要がある。

\section{参 考 文 献}

1）幸田, 井上, 熊本, 高見 : 二つの故障モードをもつ安全監視 システムの最適論理構造, 計測自動制御学会論文集, 17-9, $36 / 41(1981)$

2）田中，伊藤：モデルに起因する誤作動・不作動を考慮したモニ 
タリングシステムの設計, 第 30 回日科技連信頼性 ·保全性シ ンポジウム, 281/286(2000)

3）川村, 川本, 大内：外部観測に基づく進化的フェロモンコミュ ニケーションの評価と群知能の創発現象に関する研究, 計測 自動制御学会論文集, 37-5, 455/464(2001)

4) M.Dorigo and G.D.Caro: Ant Algorithms for Discrete Optimization, Artificial Life, 5-3, 137/172(1999)

5) E.Bonabeau, M.Dorigo and G.Theraulaz: Swarm Intclligence, Oxford University Press(1999)

6) 北村, 田中, 岸野, 谷内田: Octree とポテンシャル場を用 いた三次元環境での経路探索, 日本ロボット学会誌, 14-8, 1186/1193(1996)

7) T.Ishida: Real-Time Search for Learning Autonomous Agents, Kluwer Academic Publishers(1997)

8) S.Koenig, B.Szymanski, Y.Liu: Efficient and inefficient ant coverage methods, Annals of Mathematics and Artificial Intelligence, 31, 1-4, 41/76(2001)

9) 藤井, 淺間, 倉林, 嘉悦, 遠藤: 知的データキャリアによる群口 ボットの機能創発, 日本ロボット学会誌, 17-6, 848/854(1999)

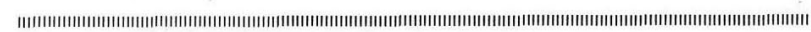

\section{[著 者 紹 介]}

石垣陽

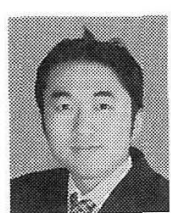

2002 年電気通信大学大学院情報システム学研 究科情報システム運用学専攻修士課程修了. 同年 セコム (株) IS 研究所入社. ネットワークセキュ リティに関する研究に従事. システム安全学と生 物機構の工学的応用に興味を持つ.

\section{田中健 次（正会員）}

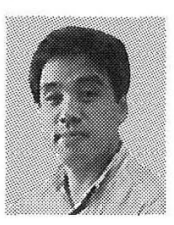

1982 年京都大学理学部数学科卒業, 89 年東京 工業大学大学院総合理工学研究科システム科学 専攻博士課程修了. 87 年上り茨城大学工学部情 報工学科助手, 95 年電気通信大学大学院情報シ ステム学研究科助教授, 現在に至る. 主としてシ ステム安全学, 信頼性の研究に従事 (理学博士). IEEE-SMC, 人工知能学会, 日本品質管理学会な どの会員.

\section{伊藤誠（正会員）}

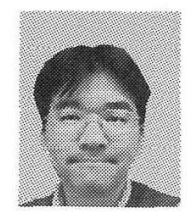

1996 年筑波大学大学院工学研究科中退, 同年筑 波大学先端学際領域研究センター助手, 98 年 10 月電気通信大学大学院情報システム学研究科助手, 2002 年より筑波大学電子・情報工学系専任講師. システム安全学を中心に, システムへの信頼と協 調, 不確実性下の意思決定などの研究に従事. 博 $士$ (工学). 第 16 回井上研究奨励賞受賞. IEEE, 日本品質管理学会などの会員. 